\title{
Strategi Komunikasi Dakwah Da'i Hidayatullah dalam Pembinaan Masyarakat Pedesaan
}

\author{
Bustanol Arifin \\ Prodi Komunikasi dan Penyiaran Islam, Program Pascasarjana, \\ UIN Sunan Gunung Djati, Bandung \\ Email: cluritemas35@gmail.com
}

\begin{abstract}
This paper aims to determine the da'i Hidayatullah da'wah communication strategy in fostering rural communities which are formulated into three questions as follows: the role of $d a^{\prime} i$ Hidayatullah in raising awareness of rural communities. The diffusion of da'i Hidayatullab's da'wab communication in fostering rural communities and the innovation of da'i Hidayatullab's da'wah communication in fostering rural communities in Cimenyan district, Bandung regency. The research method uses descriptive methods by making the da' $i$ Hidayatullah Bandung district that fosters rural communities as the main source of this research. This type of research is qualitative. The results showed that the Hidayatullah preacher had a role as a change agent by conducting persuasive-informative communication in raising and fostering rural communities in the Cimenyan sub-district, Bandung regency. The diffusion of da'wah communication carried out by Hidayatullah in developing rural communities in the Cimenyan district of Bandung district through activities in the form of majelis ta'lim, grand $M B A$, training of bina aqidah, qur'an education park (TPA) and mosque youth in which da'wah messages in the form of aqeedah, shari'ah, and morals. Da'i Hidayatullab's innovation in da'wah communication was in the form of implementing an empowerment program which included empowering buman resources (HR) and the community economy which was formed through training and recitation activities.
\end{abstract} Keywords: Communication Strategy, Da'i Hidayatullah, Coaching, Rural Community

\begin{abstract}
ABSTRAK
Tulisan ini bertujuan untuk mengetahui strategi komunikasi dakwah da’i Hidayatullah dalam membina masyarakat pedesaan yang dirumuskan menjadi tiga pertanyaan sebagai berikut: peran da'i Hidayatullah dalam menyadarkan masyarakat pedesaan. Difusi komunikasi dakwah da'i Hidayatullah dalam membina masyarakat pedesaan dan inovasi komunikasi dakwah da’i Hidayatullah dalam membina masyarakat pedesaan di kecamatan Cimenyan kabupaten Bandung. Metode penelitian menggunakan metode deskriptif dengan menjadikan da'i Hidayatullah kabupaten Bandung yang membina masyarakat pedesaan sebagai sumber utama dalam penelitian ini. Jenis penelitian adalah kualitatif. Hasil penelitian menunjukkan bahwa da'i Hidayatullah berperan sebagai agen perubah
\end{abstract}


B. Arifin

dengan melakukan komunikasi persuasif-informatif dalam menyadarkan dan membina masyarakat pedesaan di kecamatan Cimenyan kabupaten Bandung. Difusi komunikasi dakwah yang dilakukan oleh da'i Hidayatullah dalam membina masyarakat pedesaan di kecamatan Cimenyan kabupaten Bandung melalui kegiatan berupa majelis ta'lim, grand MBA, training bina aqidah, taman pendidikan al-qur'an (TPA) dan remaja masjid yang didalamnya disampaikan pesan-pesan dakwah berupa pesan aqidah, syari'ah, dan akhlak. Inovasi komunikasi dakwah yang dilakukan oleh da'i Hidayatullah berupa penyelenggaraan program pemberdayaan yang meliputi pemberdayaan sumber daya manusia (SDM) dan ekonomi masyarakat yang dibentuk melalui kegiatan pelatihan dan pengajian.

Kata kunci : Strategi Komunikasi, Da’i Hidayatullah, Pembinaan, Masyarakat Pedesaan

\section{PENDAHULUAN}

Masyarakat pedesaan masih dianggap sebagai standar dan pemelihara sistem kehidupan bermasyarakat dan kebudayaan asli berupa tolong menolong, keguyuban, persaudaraan, gotong royong, kesenian, ketaatan dalam beragama, kepribadian dalam berpakaian, adat istiadat, kehidupan moral susila, dan kebudayaan lain yang datang dari luar biasanya diperbandingkan dengan kebudayaan asli yang pada umumnya masih berlaku di daerah pedesaan untuk mengkaji manfaat dan mudharat kebudayaan baru tersebut.(Surjadi 2015:hal 23)

Akan tetapi seiring dengan perkembangan ilmu pengetahuan dan tekhnologi diikuti oleh sarana informasi dan komunikasi yang sangat pesat membuat sebagian umat manusia khususnya masyarakat pedesaan mengalami pergeseran nilai serta mulai kehilangan eksistensi jati dirinya. Dekadensi moral yang disebabkan oleh pengakuan terhadap budaya barat sebagai trend yang apabila diikuti akan mendapatkan penghargaan sosial dan tempat dikalangan tertentu.

Hal tersebut dapat dilihat dari beberapa kasus dimana adat berpakaian wanita di pedesaan sudah tidak jauh berbeda dengan perempuan di perkotaan yang berpenampilan serba ketat dan kelihatan aurat serta lekak-lekuk tubuhnya. Selain itu tingkat partisipasi masyarakat pedesaan ke pengajian dan sholat berjamaah ke masjid semakin berkurang karena disibukkan dengan sinetron dan acara televisinya, dan juga kondisi anak-anak yang lebih suka nongkrong di depan TV dan internet daripada hadir ke musholla dan pesantren.

Fenomena diatas juga dapat ditemukan di kecamatan Cimenyan kabupaten Bandung yang notabeni masyarakatnya merupakan masyarakat pedesaan. Masyarakat pedesaan yang berada di kecamatan Cimenyan kabupaten Bandung cenderung mengikuti gaya hidup modern yang datangnya dari barat. Salah satu penyebabnya adalah masifnya informasi yang didapatkan melalui saluran media massa dan internet. 
Selain itu masyarakat pedesaan di kecamatan Cimenyan juga dalam pengamalan nilai-nilai keagamaan terus mengalami penurunan. Hal ini dapat dilihat dari partisipasi masyarakat untuk menghadiri kegiatan dan atau ritual keagamaan seperti majelis ta'lim, sholat berjamaah di masjid, tadarus al-qur'an. Disamping itu, para remaja dan pemuda yang nanti diharapkan menjadi penerus estafeta kepemimpinan para orangtuanya juga mengalami hal yang sama, yakni pergaulan bebas, nongkrong, dan jauh dari istilah religiusitas. Sedangkan anakanak lebih suka nongkrong di depan TV daripada hadir ke TPA yang ada dimasjid atau musholla (wawancara: 12.18)

Hal ini tentunya sangat mengundang perhatian para juru dakwah atau organisasi keislaman untuk lebih meningkatkan lagi gerakan dakwahnya khususnya pada masyarakat pedesaan agar Islam yang salah satu misinya sebagai rahmatan lilalamin (rahmat seluruh alam) yang merupakan suatu kebenaran dapat tersebar luas dan dijadikan sebagai panduan hidup secara komprehensif. Karena dengan berpegang teguh kepada ajaran Islam seseorang atau masyarakat akan tetap teguh memegang kebenaran dan selektif terhadap segala sesuatu yang datang dalam kehidupannya.

Salah satu kegiatan dakwah yang harus intensif dilakukan oleh para juru dakwah dan organisasi Islam adalah pembinaan keislaman masyarakat desa agar menjadikan Islam sebagai jalan hidup. Dengan demikian, tujuan dakwah pada masyarakat pedesaan merupakan suatu upaya pembinaan keagamaan masyarakat agar masyarakat tersebut paham terhadap ajarannya serta mampu mengamalkan butir-butir ajaran Islam dalam kehidupan secara komprehensif dengan landasan keimanan yang benar dan kuat.

Agar tujuan dakwah dapat tercapai, maka dakwah harus dilakukan secara teratur dan terarah. Pelaksanaan dakwah yang lebih teratur dan terarah diperlukan sebuah proses. Dalam tahapan sebuah proses terdapat beberapa istilah seperti pendekatan, strategi, motode, teknik dan taktik. Pendekatan adalah sudut pandang terhadap suatu masalah, pendekatan merujuk kepada pandangan tentang terjadinya suatu proses yang sifatnya masih umum. Strategi adalah rencana strategi untuk mencapai sesuatu. Metode adalah cara untuk mencapai sesuatu. Teknik adalah cara yang lebih khusus dalam penerapan suatu metode sedangkan taktik adalah cara seseorang dalam melaksanakan suatu teknik atau metode. (Aziz: 2016 hal 208)

Oleh karenanya, sebelum dakwah dilakukan dan saat dakwah dilakukan para juru dakwah (da'i) atau organisasi dakwah terlebih dahulu harus mengetahui dan memahami realitas sosial medan dakwah yang akan dihadapi. Baru setelah itu merencanakan aksi dakwah yang akan dilaksanakan dengan cara merancang strategi dakwah yang tepat yakni merencanakan kegiatan-kegiatan dakwah yang sesuai dengan kondisi medan dakwah.

Dengan pola pengembangan dakwah seperti tersebut diatas, dakwah diharapkan membawa perubahan baik kepada individu, kelompok masyarakat 
B. Arifin

serta kondisi ke arah yang lebih baik. Karena target dari dakwah adalah terjadinya perubahan sikap dan perilaku dari masyarakat (mad'u) itu sendiri sesuai dengan ajaran Islam. Dalam pelaksanaannya, dakwah tidak melulu dilakukan oleh perorangan, akan tetapi dapat juga dilakukan oleh sekelompok orang, lembaga dan atau organisasi. Konteks dakwah yang seperti ini disebut sebagai dakwah hizbiyah (organisasional)

Sejak tahun 1990-an Hidayatullah sebagai ormas Islam telah menugaskan para da'inya untuk melakukan pembinaan kepada masyarakat pedesaan di seluruh pelosok negeri Indonesia dan salah satunya yang berada di kecamatan Cimenyen kabupaten Bandung. Hal ini dilakukan karena kondisi mayarakat pedesaan di kecamatan Cimenyen kabupten Bandung masih jauh dari istilah kemajuan, baik dari segi ekonomi, pendidikan dan khususnya pada tataran pemahaman dan praktek keagamaan yang masih banyak sekali masyarakat pedesaan kecamatan Cimenyan yang awam dengan agama Islam. Masyarakat pedesaan yang berada di kecamatan Cimenyan yang mayoritas beragama Islam masih banyak yang belum bisa mengaji dan belum bisa sholat.

Usaha-usaha dakwah yang dilakukan oleh Hidayatullah melalui para da'inya tersebut memang sangat relevan dengan kebutuhan masyarakat khususnya masyarakat pedesaan yang masih membutuhkan pembangunan dan pengembangan dibidang-bidang tersebut. Sehingga kehadiran Hidayatullah sebagai organisasi atau sebagai da'i sangat dirasakan manfaatnya oleh masyarakat pedesaan yang berada di kecamatan Cimenyan kabupaten Bandung.

Meskipun disadari bahwa masyarakat pedesaan di kecamatan Cimenyan kabupaten Bandung memiliki ciri khas tersendiri atau karakteristik yang berbeda dengan masyarakat atau daerah-daerah pedesaan yang lain. Budaya masyarakat, tingkat pendidikan, social ekonomi serta pemahaman tentang ajaran agama Islam yang berdampak pada kurang optimalnya pesan-pesan dakwah yang disampaikan kepada masyarakat. Sehingga para da'i Hidayatullah mencari strategi komunikasi dakwah yang relevan agar pesan-pesan dakwah yang disampaikan melalui kegiatan pembinaan dan bimbingan dapat diterima dengan baik oleh masyarakat.

Hal ini dapat dibuktikan dengan diterimanya da'i Hidayatullah untuk membina masyarakat pedesaan di kecamatan Cimenyan kabupaten Bandung. Mudahnya masyarakat menerima dan mengikuti kegiatan serta mengamalkan ajaran yang didakwahkan oleh para da'i Hidayatullah tentunya tidak terlepas dari strategi komunikasi dakwah yang dilakukan oleh para da'i Hidayatullah di kecamatan Cimenyan kabupaten Bandung.

Oleh karenanya, penelitian ini mencoba untuk mengetahui tentang strategi komunikasi dakwah da'i Hidayatullah dalam membina masyarakat pedesaan yang dirumuskan dalam beberapa pertanyaan. Pertama, bagaimana peran da’i Hidayatullah dalam menyadarkan masyarakat pedesaan di kecamatan Cimenyan kabupaten Bandung. Kedua, bagaimana difusi komunikasi dakwah da’i 
Hidayatullah dalam membina masyarakat pedesaan di kecamatan Cimenyan kabupaten Bandung. Ketiga, bagaimana inovasi komunikasi dakwah da’i Hidayatullah dalam membina masyarakat pedesaan.

Penelitian ini menggunakan motode deskriptif. Metode deskriptif bertujuan melukiskan secara sistematis fakta atau karakteristik populasi tertentu atau bidang tertentu secara faktual dan cermat. Penelitian deskriptif hanyalah memaparkan situasi atau peristiwa, tidak mencari atau menjelaskan hubungan, tidak menguji hipotesis atau membuat prediksi. Data yang dikumpulkan adalah berupa kata-kata, gambar, dan bukan angka-angka.

\section{HASIL DAN PEMBAHASAN}

Masyarakat kabupaten Bandung umumnya menganut agama Islam serta memiliki nilai adat yang masih cukup kental, tingkat pendidikan masyarakat perkotaan kabupaten Bandung sudah berkembang dengan baik, namun hal ini tidak sama halnya dengan perkembangan masyarakat kabupaten Bandung di pedesaan. Hal ini sangat terlihat apalagi dalam ruang lingkup masyarakat pedesaan, khususnya masyarakat desa Cimenyan,desa Mandala Mekar, desa Tugu, dan desa Cibanteng di kecamatan Cimenyan kabupaten Bandung.

Masyarakat di daerah ini rata-rata bekerja sebagai petani dan peternak serta tingkat pendidikannya masih rendah. Penghasilan serta pekerjaan mereka sebagai petani dan peternak belum mampu meningkatkan kesejahteraan hidup mereka dengan baik. Kehidupan di desa Cimenyan, desa Mandala Mekar, Tugu, Cibanteng dapat dikatakan sederhana, pendidikan yang rendah membuat mereka juga memiliki keterbatasan dalam mencari pekerjaan, sehingga mereka lebih memilih menjadi petani dan peternak. Disamping itu masyarakat di empat desa ini dalam hal pengamalan ajaran agama Islam masih jauh dari apa yang disebut dengan kata ideal. Hal ini lebih disebabkan tidak adanya atau kurangnya seorang da'i yang mampu mengajari, menyampaikan dan membina masyarakat di desa tersebut. Lokasi yang jauh serta medan dakwah yang sangat sulit dijangkau juga menjadi alasan seorang da'i untuk terjun mendampingi dan memberikan pencerahan kepada masyarakat. Sehingga masyarakat yang berada di kecamatan Cimenyan khususnya di desa Mandala Mekar dan desa Cimenyan tidak dapat melaksanakan kegiatan ibadah dengan bimbingan yang benar, serta tidak mendapatkan informasi tentang pesan-pesan agama Islam secara komprehensif. Namun setelah diadakannya pembinaan yang dilakukan oleh da'i Hidayatullah kehidupan keagamaan masyarakat desa Cimenyan dan desa Mandala Mekar berkembang lebih baik.

\section{Peran Da'i Hidayatullah dalam menyadarkan masyarakat pedesaan di kecamatan Cimenyan kabupaten Bandung}

Memperhatikan tentang perjalanan panjang da'i Hidayatullah dalam melakukan pembinaan kepada masyarakat pedesaan di kecamatan Cimenyan kabupaten 
B. Arifin

Bandung. Sejak tahun 2000 yang dimulai oleh Ainur Rofiq sebagai orang pertama yang melalukan pembinaan dan menyampaikan pesan-pesan dakwah kepada masyarakat, hingga kini kegiatan pembinaan masih terus berlanjut dan eksis. Tentu hal ini tidak akan terlepas dari apa yang disebut dengan proses yang dilalui dengan tahapan-tahapan yang bertujuan untuk menyadarkan masyarakat di pedesaan. Tahapan-tahapan yang ada dalam kegiatan pembinaan yang dilakukan oleh da'i Hidayatullah menjadi landasan awal untuk menentukan corak dan strategi yang mampu mengantarkan masyarakat kepada cita-cita ideal. Tahapantahapan yang dilakukan dalam kegiatan pembinaan tersebut antara lain:

Pertama, permasalahan. Merupakan suatu objek tertentu yang diyakini oleh da’i (agen perubah) yang akan menjadi jawaban dari sebuah permasalahan yang ada. Disini yang menjadi permasalahan adalah masyarakat pedesaan yang berada di kecamatan Cimenyan kabupaten Bandng itu sendiri yang secara umum masih tertinggal dalam segala bidang, baik sumber daya manusia, sumber daya alam dan sumber daya ekonomi. Sehingga kegiatan pembinaan disini dianggap sebagai pemecah permasalahan yang ada pada masyarakat pedesaan kecamatan Cimenyan kabupaten Bandung. Pembinaan masyarakat pedesaan di kecamatan Cimenyan kabupaten Bandung bermaksud untuk menjadikan masyarakat yang punya peradaban tinggi, masyarakat yang tingkat pemahaman dan pengamalan terhadap nilai-nilai agama tinggi, masyarakat dengan sumber daya manusia yang berkualitas dan mumpuni, serta masyarakat dengan perekonomian yang mandiri.

Kedua, agen perubah. Individu, organisasi, kelompok yang berusaha untuk membawa perubahan masyarakat melalui kegiatan pembinaan. Dalam kegiatan pembinaan ini yang menjadi agen perubah adalah da'i Hidayatullah sendiri yakni Iryana Muhammad, Hendro Eko Putra, Sayyid Imaduddin yang dibantu oleh Asnawawi Auli dan Hari Arvan Maulana serta tokoh masyarakat, DKM, pejabat pemerintah daerah setempat yang sudah melakukan transaksi kerjasama untuk bersama-sama memajukan masyarakat pedesaan.

Ketiga, media atau saluran. Komunikasi dan distribusi dijadikan sebagai media, dimana pengaruh dan respon nantinya akan merubah masyarakat. Media yang digunakan dalam pembinaan dan proses penyampaian pesan-pesan keagamaan kepada masyarakat pedesaan di kecamatan Cimenyan kabupaten Bandung bukanlah media elektronik dan media massa pada umumnya. Namun media yang digunakan dalam menyampaikan pesan-pesan dakwah oleh da'i Hidayatullah dengan komunikasi interpersonal yang berupa perbincangan dalam sebuah forum yang berbentuk pengajian, penyuluhan, dan pelatihan. Dimana dalam kegiatan ini menjadi media antara da'i dan masyarakat bersama-sama membahas tentang permasalahan kehidupan yang ada. Komunikasi interpersonal dijadikan sebagai media dalam menyampaikan pesan-pesan dakwah kepada masyarakat karena dalam penggunaan media elektronik dianggap tidak atau kurang efektif. 
Keempat, peran pengubah. Pengarahan dan adopsi program yang dilakukan oleh agen perubah (da'i) untuk memberikan dampak perubahan sikap dan perilaku pada masyarakat pedesaan. Peran da'i Hidayatullah dalam memberikan dampak perubahan sikap serta perilaku pada masyarakat ini terlebih dahulu dimulai dengan pengkondisian masyarakat untuk membentuk nilai-nilai kebersamaan, persaudaraan, kesolidan bersama. Selain itu juga da'i disini harus mampu membangun kepercayaan kepada masyarakat pedesaan yang ada di kecamatan Cimenyan kabupaten Bandung. Karena apabila kepercayaan sudah terbentuk antara da'i dengan masyarakat, secara otomatis nilai-nilai persaudaraan, kepedulian, kebersamaan dan kesolidan akan dengan sendirinya terbangun dan terbentuk, sehingga penerimaan pesan-pesan dakwah yang disampaikan oleh da'i Hidayatullah akan lebih mudah diterima oleh masyarakat pedesan di kecamatan Cimenyan kabupaten Bandung.

Selain melalui tahapan-tahapan dalam proses penyadaran masyarakat pedesaan di kecamatan Cimenyan kabupaten Bandung. Da’i Hidayatullah juga melakukan langkah-langkah atau strategi yang dapat mempermudah dalam menyampaikan pesan-pesan dakwah kepada masyarakat. Hal ini dilakukan melalui dengan sebuah pemetaan masyakat sebagai obyek yang akan menerima pesanpesan dakwah.

Pemetaan masyarakat didasarkan atas dua kriteria sebagai berikut: Pertama, masyarakat digolongkan atau dikelompokkan sesuai dengan kemampuan dalam memahami pesan dakwah yang disampaikan oleh da'i Hidayatullah. Kemampuan yang dimaksud adalah kemampuan dalam memahami, mencerna, membaca pesanpesan dakwah yang dilakukan oleh da'i Hidayatullah kepada masyarakat pedesaan dalam proses pembinaan. Kemampuan masyarakat pedesaan di kecamatan Cimenyan kabupaten Bandung dipetakan menjadi tiga bagian seusia dengan jenjang usia yang meliputi orang tua (bapak-bapak dan ibu-ibu ), remaja atau pemuda (usia 15 hingga 3o tahun ), anak-anak usia tujuh hingga 14 tahun. Dengan pemetaan masyarakat yang digolongkan sesuai dengan kemampuan tersebut, maka pesan dakwah yang disampaikan oleh da'i Hidayatullah dapat dengan mudah diterima oleh masyarakat. Karena dalam pemilihan pesan akan disesuaikan dengan kemampuan dari masing-masing bagian atau masyarakat yang sudah terpetakan.

Kedua, masyarakat dikelompokkan atau digolongkan berdasarkan kebutuhan dari masyarakat itu sendiri. Kebutuhan yang dimaksud terkait dengan pengajaran atau pesan-pesan dakwah yang akan disampaikan oleh da'i Hidayatullah kabupaten Bandung. Untuk kalangan orang tua dengan usia 50 sampai 70 tahun, mereka membutuhkan pesan-pesan dakwah yang dapat mengantarkan mereka melakukan atau dapat dilaksanakan dalam kehidupan sehari, amalan ini meliputi sholat wajib lima waktu, tata cara bersuci, aqidah atau keimanan serta akhlak terhadap Allah dan kepada sesama manusia. Sehingga pesan yang disampaikan kepada masyarakat golongan ini terkait dengan masalah ibadah dan thaharah, aqidah serta akhlak. Adapun untuk kalangan remaja, mereka lebih dari sekedar ritual ibadah saja. Akan 
B. Arifin

tetapi mereka membutuhkan pengetahuan tentang Islam secara kenfrehensif dan koherean sehingga dapat mengilmui serta mengamalkan ilmu yang telah mereka dapatkan. Sedangkan untuk kalangan anak-anak, mereka lebih membutuhkan figure yang dapat dicontoh dalam kehidupan sehari mereka, dengan pola kegiatan pembiasaan untuk menumbuhkan karakter qur'ani dalam diri mereka. Mereka tidak membutuhkan penjelasan panjang lebar dan juga praktek atau dalil yang lengkap, cukup dengan contoh mereka akan dengan mudah menerima pesanpesan agama serta dapat dengan mudah mengamalkan dalam kehidupan seharihari.

\section{Difusi komunikasi dakwah da'i Hidayatullah dalam membina masyarakat pedesaan di kecamatan Cimenyan kabupaten Bandung}

Difusi merupakan sebuah proses bagaimana suatu inovasi dikomunikasikan lewat channel (media) tertentu sepanjang waktu kepada anggota kelompok dari suatu sistem sosial. "Diffusion is the process by which an innovation is communicated through certain channels over time among the members of a social system." Sesuai dengan pemikiran Rogers, dalam proses difusi terdapat 4 (empat) elemen pokok, yaitu: inovasi, saluran komunikasi, jangka waktu, dan sistem social.

Diantara bentuk difusi komunikasi dakwah yang telah dilakukan oleh da'i Hidayatullah dalam proses pembinaan masyarakat pedesaan antar lain: 1). Majelis ta'lim 2). Training bina aqidah 3). TPA 4). Grand MBA 5). Remaja Masjid. Kelima program ini kemudian menjadi kegiatan yang rutin dilaksanakan oleh da'i Hidayatullah sebagai media menyampaikan pesan-pesan dakwah untuk mewujudkan masyarakat yang islami.

Majelis ta'lim merupakan salah satu difusi komunikasi dakwah da'i Hidayatullah yang dilakukan kepada masyarakat pedesaan di kecamatan Cimenyan kabupaten Bandung. Melalui majelis ta'lim da'i Hidayatullah menyampaikan pesan-pesan dakwahnya kepada masyarakat pedesaan yang dilaksanan setiap pekan sekali dan setiap bulan sekali di masjid desa yang ada. Masyarakat dengan antusiasme yang tinggi mengikuti kegiatan majelis ta'lim ini, mereka menyimak dan memperhatikan setiap untaian kalimat yang disampaikan oleh da’i Hidayatullah kepada mereka. Hal ini dibuktikan dengan jumlah masyarakat yang hadir ke majelis ta'lim semakin hari semakin bertambah sebagai bukti bahwa komunikasi yang dilakukan oleh da'i Hidayatullah dapat dikatakan sebagai komunikasi yang efektif. Selanjutnya adalah kegiatan training bina aqidah menjadi difusi komunikasi dakwah da'i Hidayatullah dalam membina masyarakat pedesaan kecamatan Cimenyan kabupaten Bandung. Training bina aqidah merupakan wadah bagi da'i dan masyarakat untuk dapat mengetahui bersama tentang materi penguatan aqidah dan keimanan yang disampaikan oleh seorang da'i. Melalui kegiatan training bina aqidah da'i Hidayatullah menyampaikan pesan-pesan aqidah kepada masyarakat dan memberikan warning agar senantiasa untuk menjaga, menguatkan aqidah atau keyakinan kepada Allah. 
Selain menyasar masyarakat yang terdiri dari ibu-ibu dan bapak-bapak, da’i Hidayatullah juga menjadikan anak-anak dan remaja sebagai sasaran penerima difusi komunikasi dakwah mereka. Pembentukan TPA oleh da'i Hidayatullah merupakan cara mereka untuk menyampaikan pesan-pesan dakwah kepada anakanak yang di desa kecamatan Cimenyan kabupaten Bandung. Anak-anak dengan gegap gembita gembira mengikuti kegiatan mengaji dan belajar agama kepada da’i Hidayatullah setiap selesai sholat maghrib hingga isya'. Untuk kalangan remaja yang dilakukan da'i Hidayatullah adalah membentuk remaja masjid. Mereka dibina dalam bentuk komunitas yang didalamnya disampaikan pesan-pesan agama serta motivasi untu terus meningkatkan kualitas pribadi sebagai hamba dan sebagai bagian masyarakat yang akan menggantikan para orang tua mereka jika mereka sudah tiada.

Secara umum penerapan kegiatan pembinaan masyarakat pedesaan yang dilakukan dengan membentuk kegiatan mejelis ta'lim, training bina aqidah, TPA, Remaja Masjid dan Grand MBA dapat diteriman oleh masyarakat dengan baik. Hal ini disebabkan karena pemberdayaan baik manusia maupun ekonomi bukan dilihat hanya berdasarkan pembangunan semangat dalam diri masyakat pedesaan kecamatan Cimenyan kabupaten Bandung. Namun lebih dari itu, kegiatan pemberdayaan manusia dan ekomoni melaui kegiatan-kegiatan tersebut diatas langsung dirasakan oleh masyarakat.

Dalam proses pembinaan masyarakat pedesaan di kecamatan Cimenyan kabupaten Bandung yang dilakukan oleh da'i Hidayatullah difusi komunikasi dakwah berupa pesan-pesan yang akan disampaikan kepada masyarakat adalah sebuah keniscayaan. Sehingga pada tataran pelaksanaannya pesan yang disampaikan oleh da’i Hidayatullah dapat diterima oleh masyarakat dan dapat mengubah perilaku masyarakat itu sendiri. Difusi komunikasi dakwah berupa pesan-pesan dakwah yang disampaikan oleh da'i Hidayatullah dalam membina masyarakat pedesaan di kecamatan Cimenyan terdiri dari beberapa kategori yakni;

Pertama, pesan aqidah. Pesan aqidah merupakan pesan pertama dan utama yang disampaikan oleh da'i Hidayatullah dalam melakukan pembinaan kepada masyarakat pedesaan di kecamatan Cimenyan kabupaten Bandung. Pesan aqidah ini disampaikan oleh da'i Hidayatullah melalui majelis ta'lim yang diselenggarakan setiap sepekan sekali atau sebulan sekali. Bentuk dari pesan aqidah itu meliputi keimanan kepada Allah, malaikat, nabi dan rasul, kitab-kitab, hari kiamat dan taqdir baik dan buruk yang terkumpul dalam rukun iman yang enam. Selain itu syahadat dan rukun serta syaratnya juga menjadi bagian tak terpisahkan dari bentuk pesan yang disampaikan kepada masyarkata pedesaan di kecamatan Cimenyan kabupate Bandung. Syahadat yang tertmaktub dalam rukun islam dan berada urutan pertama dalam sebuah hadist nabi. Kedua, pesan syari'ah. Setelah pesan aqidah tersampaikan, pesan selanjutnya yang disampaikan kepada masyarakat pedesaan kecamatan Cimenyan kabupaten Bandung adalah pesan syari'ah. Pesan syari'ah ini dititik beratkan pada pemahaman fiqh dasar yang 
B. Arifin

miliputi fiqih thaharah, ibadah, dan muamalah. Hal ini disebabkan karena masyarakat pedesaan di kecamatan Cimenyan kabupaten Bandung mayoritas belum mengetahui tentang figh tersebut di atas. Baik itu yang berkaitan dengan thaharah (bersuci), maupun masalah sholat. Dalam tataran prakeknya pesan dakwah dalam bingkai syari'ah mengharapkan agar masyarakat pedesaan di kecamatan Cimenyan kabupaten Bandung mengerti dan paham tentang bagaimana cara beribadah dengan baik dan benar. Masyarakat dengan pendidikan yang rata-rata hanya lulusan SD merasa sangat berat dalam memahami pesanpesan syari'ah tersebut, hanya penyampaian materi dilakukan dengan cara yang mudah dan dapat diaplikasikan secara langsung oleh masyarakat. Sholat misalnya, disamping disampaikan tentang bagaimana cara sholat yang baik dan benar juga masyarakat diajak untuk melaksanakan sholat berjama'ah di masjid. Bagitu halnya dengan bersuci, masyarakat tidak diajarkan untuk mengetahui dan memahami barang, binatang, makanan dan minuman apa yang saja yang tidak boleh dikonsumsi akan tetapi masyarakat juga diajak untuk melakukan kepedulian sosial terhadap lingkungan sekitar. Ketiga, pesan akhlak. Rumusan pesan akhlak menjadi salah satu pesan yang disampaikan oleh da'i Hidayatullah dalam membina masyarakat pedesaan di kecamatan Cimenyan kabupaten Bandung. Pesan akhlak merupakan pesan yang berisi tentang bagaimana seseorang berinterasksi antar sesama, dengan lingkungan, dengan tuhan sesuai dengan apa yang dicontohkan

oleh Nabi Muhammad. Kepribadian muslim sejati adalah menjadikan nabi Muhammad sebagai panutan dalam berinteraksi dengan tuhan, manusia, dan alam yang termanifestasikan dalam lingkup kehidupan sehari-hari. Dengan disampaikannya materi akhlak kepada masyarakat pedesaan di kecamatan Cimenyan kabupaten Bandung diharapkan mampu meneladani akhlak mulia rasulullah serta sebagai kewajiban sesama musliam untuk menyanpaikan tentang risalah yang dibawa oleh nabi Muhammad.

\section{Inovasi komunikasi dakwah da'i Hidayatullah dalam membina masyarakat pedesaan di kecamatan Cimenyan kabupaten Bandung}

Inovasi merupakan sebuah gagasan atau ide, tindakan atau suatu produk yang dianggap baru oleh orang lain. Dalam penelitian ini yang dimaksud inovasi adalah gagasan dan tindakan yang dilakukan oleh da'i Hidayatullah dalam membina masyarakat pedesaan di kecamatan Cimenyan kabupaten Bandung. Sejak awal da’i Hidayatullah menjadikan kecamatan Cimenyan sebagai prioritas pembinaan masyarakat. Hal ini dilakukan untuk membentengi aqidah masyarakat pedesaan dari ajaran-ajaran agama lain yang datang untuk mengajaka masyarakat meyakini agama mereka.

Inovasi komunikasi dakwah yang dilakukan oleh da'i Hidayatullah berawal dari sebuah gagasan yang muncul dari da'i Hidayatullah sendiri, yakni terwujudnya kehidupan masyarakat pedesaan di kecamatan Cimenyan kabupaten Bandung secara islami, baik islami dalam pola pikir, pola hidup dan menjadi percontohan 
bagi daerah lain dalam tatanan kehidupan masyarakat yang islami. Gagasan ini kemudian diwujudkan dalam bentuk tindakan berupa pembinaan kepada masyarakat pedesaan yang berada di kecamatan Cimenyan kabupaten Bandung.

Diantara bentuk inovasi yang telah dilakukan oleh da'i Hidayatullah dalam proses pembinaan masyarakat pedesaan antar lain: 1). Pemberdayaan Sumber Daya Manusia (SDM) 2). Pemberdayaan Ekonomi Masyarakat .Kedua program ini kemudian menjadi kegiatan yang rutin dilaksanakan oleh da'i Hidayatullah sebagai media menyampaikan pesan-pesan dakwah untuk mewujudkan masyarakat yang islami.

Dalam kegiatan dakwah tentunya ada produk yang akan ditawarkan kepada masyarakat. Dalam hal ini gagasan berupa pemberdayaan masyarakat baik pemberdayaan secara ekonomi maupun pemberdayaan sumber daya manusia merupakan produk dakwah yang ditawarkan kepada masyarakat pedesaan yang ada di kecamatan Cimenyan kabupaten Bandung yang menjadi target pembinaan oleh da'i Hidayatullah. Masyarakat pedesaan di kecamatan Cimenyan dijadikan sebagai target dalam kegiatan dakwah berupa pembinaan ini karena diharapkan kesejahteraan masyarakat yang dihiasi dengan nilai-nilai agama Islam dapat mewujud dalam bentuk nyata dan menjadi lebih baik dari sebelumnya.

Peran serta strategi komunikasi dakwah yang digunakan oleh da'i Hidayatullah dalam menyadarkan masyarakat pedesaan adalah dengan melakukan pemberdayaan masyarakat yang dibagi menjadi dua bentuk. Pertama, pemberdayaan sumber daya manusia (SDM). Kedua, pemberdayaan ekonomi. Kedua program ini dapat dirinci sebagai berikut: dalam melalukan program pemberdayaan sumber daya manusia (SDM), da’i Hidayatullah melakukan pembinaan kepada masyarakat pedesaan di kecamatan Cimenyan kabupaten Bandung dengan memberikan beasiswa pendidikan bagi keluarga yang tidak mampu. Target dari program ini adalah anak-anak yang sudah lulus SD dan akan melanjutkan ke jenjang pendidikan yang lebih tinggi. Program besasiswa pendidikan ini diharapkan dapat membantu melahirkan manusia-manusia yang berkualitas, beriman, bertakwa dan berjiwa kesatria serta membawa perubahan untuk bangsa dan Negara. Sedangkan merealisasikan program pemberdayaan ekonomi masyarakat pedesaan di kecamatan Cimenyan kabupaten Bandung, da'i Hidayatullah memberikan pelatihan-pelatihan life skill bagi masyarakat yang membutuhkan. Target dari program ini adalah para ibu rumah tangga yang belum mempunyai pekerjaan selain menjadi istri. Para bapak yang belum punya pekerjaan tetap dan sudah bekerja tapi masih bekerja kepada orang lain. Para remaja yang sudah lulus SMA tapi tidak bisa melanjutkan kuliah atau yang belum penya pekerjaan. Bentuk dari program pelatihan life skill (kehalian) yang didalakukan oleh da'i Hidayatullah kepada masyarakat pedasaan di kecamatan Cimenyan kabupaten Bandung adalah pelatihan atau kursus menjahit bagi ibu-ibu, beternak, berkebun atau bertani bagi bapak-bapak dan otomotif, perbengkelan bagi para remaja.

Pelaksanaan strategi komunikasi dakwah mempunyai tahapan awal yang 
B. Arifin

disebut dengan tahap pengetahuan. Dalam beberapa kasus sosial umumnya tahap pengetahuan tujuan utamanya adalah untuk menyadarkan atau menginformasikan kepada masyarakat akan adanya inovasi dan adanya pemahaman tertentu tentang bagaimana inovasi tersebut berfungsi. Dalam tahap ini seseorang belum mengetahui informasi mengenai sebuah inovasi baru tersebut. Untuk itu informasi mengenai inovasi tersebut harus disampaikan melalui media massa, media elektronik maupun komunikasi interpersonal di antara mereka.

Pertama, pengetahuan. Pada tahapan pengetahuan dalam pembinaan masyarakat pedesaan di kecamatan Cimenyan ini adalah menyampaikan dan menginformasikan pesan-pesan dakwah dalam upaya menyadarkan masyarakat pedesaan di kecamatan Cimenyan untuk meningkatkan taraf hidup masyarakat tersebut. Pada tahap pemberian informasi atau pengetahuan ini, maka peran seorang da'i sangat dibutuhkan oleh masyarakat yang akan menerima pesan-pesan dakwah. Peran da'i sebagai penyampai informasi sangat dibutuhkan oleh masyarakat yang ada di pelosok pedesan yang sangat minim pembinaan maupun penyuluhan keagamaan. Sehingga dengan kehadiran seorang da'i ditengah-tengah mereka dapat memberikan informasi mengenai ajaran agama Islam

Informasi yang disampaikan kepada masyarakat merupakan informasi yang sesuai dengan kebutuhan masyarakat setempat. Maka langkah pertama yang dilakukan adalah menyampaikan kepada masyarakat akan pentingnya sebuah kebersamaan yang dengan kebersamaan itu akan muncul ikatan persaudaraan yang erat dan kuat, yang kemudian melahirkan sifat tolong menolong, peduli dan punya kemauan untuk melakukan perubahan bersama. Tahapan pengetahuan yang dilakukan oleh da'i Hidayatullah kepada masyarakat pedesaan untuk melakukan perubahan kepada masyarakat tidak menggunakan media massa karena penyebaran pesan-pesan dakwah melalui media massa dianggap tidak efektif. Hal ini disebabkan karena tingkat pendidikan masyarakat pedesaan yang berada di kecamatan Cimenyan kabupaten Bandung rata-rata masih rendah.

Kedua, persuasi. Pada tahap persuasi ini, masyarakat yang menerima informasi tentang sebuah inovasi akan mempertimbangkan untuk menerima atau menolak inovasi tersebut. Hal ini dilakukan setelah mereka menerima informasi dan kemudian didiskusikan atau dikomunikasikan dengan orang lain.

Setelah masyarakat mau untuk menerima perubahan yang disampaikan dan dibawa oleh para da'i melalui pertimbangan yang matang, maka selanjutnya masyarakat tersebut dapat mengikuti kegiatan yang telah diberikan oleh para da'i tersebut, dalam hal ini da'i Hidayatullah. Pertimbangan untuk menerima inovasi yang disampaikan oleh da'i kepada masyarakat di desa Cimenyan dan desa Mandala Mekar merupakan pertimbangan yang mampu menjawab kegelisahan masyarakat yang selama sekian lama belum ada orang yang siap membina mereka. Maka ketika da'i Hidayatullah datang di tengah-tengah mereka, mereka memilih untuk menerima inovasi atau tawaran pembinaan da’i tersebut. 
Butuh proses dan waktu yang cukup lama untuk menumbuhkan atau menyadarkan masyarakat. Baru kemudian setelah masyarakat menerima akan perubahan yang disampaikan oleh para da'i, mereka kemudian membuat program yang tujuannya adalah untuk memahamkan kepada masyarakat tentang ajaran agama Islam, sehingga terwujudnya tatanan kehidupan masyarakat yang ideal sesuai dengan cita-cita Islam itu sendiri. Kegiatan pertama yang dilaksanakan adalah memakmurkan masjid pedesaan. Masjid menjadi salah satu indikator dari efektif atau tidak sebuah pesan yang disampaikan. Kegiatan memakmurkan masjid ini dimulai dengan membersihkan masjid, menjaga dan merawat masjid, kemudian mengadakan kegiatan-kegiatan keagamaan seperti sholat berjamaah di masjid, majelis taklim, TPA dan remaja masjid.

Ketiga, keputusan. Tahap keputusan merupakan tahapan keputusan individu atau masyarakat yang membawa mereka pada suatu pilihan untuk mengambil dan mengadopsi sebuah inovasi yang disampaikan oleh agen perubahan. Namun setelah membuat keputusan akhir baik menolak atau menerima inovasi, lantas tidak menutup kemungkinan terdapat perubahan dalam pengabdosian. Masyarakat yang sudah diterpa oleh informasi atau pesan tentang adanya sebuah kegiatan pengajian, sebagian dari mereka menerima dan mengikuti kegiatan tersebut. Akan tetapi hanya beberapa kali saja, setelah itu mereka berhenti dan tidak pernah datang untuk mengikuti pengajian. Sehingga strategi lagi untuk meyakinkan masyarakat dan membujuk masyarakat untuk menerima dan mengikuti kegiatan pengajian yang dilaksanakan setiap sepekan, sebulan sekali.

Begitu pula dengan remaja dan anak-anak yang ada di TPA, mereka harus diberikan stimulus agar mau mengikuti kegiatan belajar setiap sore hari. Karena mereka lebih memilih bekerja membantu orang tua mereka dari pada datang ke masjid untuk mengikui kegiatan mengaji. Juga lebih memilih bermain dengan teman sebaya dari pada mengikuti kegiatan mengaji di masjid. Pendekatan secara persuasive dilakukan kepada anak-anak yang ada di desa Tugu dan Lebak Gede agar mereka mau datang ke masjid untuk belajar mengaji. Selain pendekatan persuasive kepada anak-anak dan remaja, juga dilakukan pendekatan kepada para orang tua mereka, agar mereka mau mengirimkan anaknya untuk belajar di masjid. Hal ini bisa dilakukan dengan datang dari rumah ke rumah atau dari warung ke warung.

Selain pendekatan persuasive dan silaturrahim dengan para orang tua, juga dilakukan penyesuaian waktu mengaji. Karena kebanyakan dari anak-anak yang ada di desa Tugu dan Lebak Gede masih sekolah. Mereka sekolah di waktu pagi hingga siang hari, sehingga sore harinya mereka bisa mengaji di masjid. Sedangkan yang sekolah dari siang hingga sore, mereka tidak bisa datang ke masjid untuk belajar agama. Sehingga langkah yang dilakukan adalah menyesuaikan waktu belajar mengaji disesuaikan dengan waktu pulang sekolah anak-anak dan remaja, yakni setelah sholat maghrib hingga isya'. Meskipun demikian, masih banyak anakanak dan remaja khusunya yang masih belum mau datang ke masjid untuk belajar 
B. Arifin

agama. Mereka datang ke masjid ketika mereka mau, jika mereka tidak mau mereka tidak datang ke masjid. Dengan demikian cara yang terakhir dugunakan adalah dengan memanggil anak-anak dan remaja untuk datang ke masjid menggunakan pengeras suara. Kadang-kadang juga dilakukan tadarus al-Qur'an untuk memancing anak-anak dan remaja untuk bisa hadir ke masjid.

Keempat, konfirmasi. Dalam proses pembinaan dan pemberdayaan masyarakat pedesaan di kecamatan Cimenyan kabupaten Bandung yang dilakukan oleh da'i Hidayatullah sejak tahun 2011 hingga sekarang berjalan dengan baik dan lancer dan sangat membantu dalam melakukan pola pikir masyarakat dan membantu perubahan sikap dan perilaku masyarakat pedesaan di kecamatan Cimenyan kabupaten Bandung. Namun semenjak tahun 2015-2017 kegiatan pemberdayaan masyarakat pedesaan mengalami penurunan. Hal ini lebih disebabkan oleh da'i Hidayatullah yang setiap saat bisa berganti atau berhenti untuk melakukan penyampaian pesan-pesan dakwah kepada mayarakat. Berhenti disini yang dimaksud adalah da'i Hidayatullah yang melakukan pembinaan dan pemberdayaan masyarakat banyak yang ditugaskan ke tempat lain. Sehingga masyarakat yang bina mengalami kekosongan agen perubah.

\section{PENUTUP}

Pembinaan masyarakat yang merupakan salah satu objek dakwah tidak akan terlepas dari yang namanya strategi komunikasi. Ia merupakan satu kesatuan yang saling melengkapi satu sama lain. Sejak awal masyarakat pedesaan di kecamatan Cimenyan kabupaten Bandung merupakan masyarakat dengan penganut agama Islam, namun masih banyak masyarakat yang belum memahami tentang Islam secara baik dan benar. Hal ini disebabkan karena masuknya budaya baru yang mempengaruhi gaya kehidupan masyarakat dan kurangnya pembimbing agama yang senantiasa membimbing masyarakat untuk mengamalkan nilai-nilai ajaran Islam. Sebagai seorang da'i, termasuk da'i Hidayatullah harus mencari cara agar penyampaian pesan-pesan dakwah dengan tujuan akhir mengubah sikap dan perilaku masyarakat agar dapat mengamalkan nilai-nilai ajaran Islam dapat tersampaikan dengan baik dan diterima oleh masyarakat.

Dari sekian banyak pembahasan yang sudah dipaparkan, dapat ditarik kesimpulan sebagai berikut: Pertama, Peran da'i Hidayatullah dalam menyadarkan masyarakat pedesaan melalui komunikasi persuasif dan informatif membuat masyarakat sadar akan pentingnya kebersamaan yang melahirkan kepedulian, persaudaraan dan kekompakan diantara mereka. Melalui kegiatan pemetaan masyarakat yang ditujukan agar proses penyampaian pesan dapat dengan mudah diterima dan diamalkan oleh masyarakat yang meliputi pemetaan sesuai dengan kemampuan dan kebutuhan masyarakat itu sendiri dengan memperhatikan usia, tingkat pendidikan, ekonomi, strata social serta kemampuan dalam menerima pesan-pesan dakwah yang dilakukan oleh da'i Hidayatullah. Kedua, Difusi 
komunikasi dakwah yang dilakukan oleh da'i Hidayatullah dalam proses pembinaan masyarakat pedesaan telah menarik perhatian banyak masyarakat untuk mengikuti dan mengamalkan pesan-pesan dakwah yang mereka dapatkan. Melalui kegiatan majelis ta'lim, training bina aqidah serta grand MBA (Gerakan Bersama Membaca Belajar Alqur'an) untuk kalangan oran tua yang terdiri dari bapak-bapak dan ibu-ibu. Untuk kalangan anak-anak, Taman Pendidikan Alqur'an (TPA) menjadi daya tarik tersendiri bagi mereka untuk belajar membaca Alqur'an, do'a sehari-hari dan memperbaiki akhlak kepada sesama. Begitu juga dengan kalangan remaja mereka sangat antusias mengikuti kegiatan pembinaan remaja masjid yang digembleng oleh da'i-da'i tangguh Hidayatullah.

Ketiga, Inovasi komunikasi dakwah yang disampaikan oleh da'i Hidayatullah kepada masyarakat pedesaan merupakan inovasi yang sangat dibutuhkan oleh masyarakat pedesaan di kecamatan Cimenyan kabupaten Bandung. Kegiatan pemberdayaan yang dilakukan oleh da'i Hidayatullah berupa pemberdayaan sumber daya manusia (SDM) dan pemberdayaan ekonomi masyarakat yang dikemas dengan bentuk pemberian beasiswa pendidikan mulai dari tingkat SMP hingga perguruan tinggi. Juga pelatihan life skill (keahlian khusus) berupa menjahit, beternak dan bengkel bagi masyarakat untuk meningkatkan tingkat perekonomian mereka.

Keberhasilan dakwah melalui kegiatan pembinaan masyarakat pedesaan yang dilakukan oleh da'i Hidayatullah disebabkan penentuan strategi komunikasi dakwah yang relevan dan sesuai dengan kebutuhan masyarakat. Hal ini bukan berarti menafikan adanya kekurangan dalam penerapan strategi komunikasi dakwah dalam membina masyarakat. Oleh karenya perlu kiranya saran serta masukan disampaikan dalam rangka perbaikan serta penyempurnaan untuk keberhasilan kegiatan dakwah kedepannya, baik untuk da’i Hidayatullah sendiri maupun bagi yang lainnya.

Dalam memulai kegiatan dakwah hendaknya para da'i menggunakan pendekatan yang dapat membuat masyarakat tertarik untuk mengikuti ajakan tersebut. dengan membangun trust (kepercayaan) dikalangan masyarakat, memberikan solusi dalam mengatasi tumpang tindih permasalahan yang dihadapi oleh masyarakat itu sendiri serta menjadi teladan dalam kehidupan pribadi, keluarga, masyarakat, bangsa dan Negara.

\section{DAFTAR PUSTAKA}

Aziz, Ali M. (2009). Ilmu Dakwah, Jakarta: Prenada Media Group.

Effendy, Uchjana O. (2004). Dinamika Komunikasi, Bandung: PT. Remaja Rosdakarya.

Efendy, Uchjana O. (1984). Ilmu Komunikasi Teori dan Praktek, Bandung: PT. Remaja Rosdakarya

Cangara, H. (2002). Pengantar Ilmu Komunikasi. Jakarta: Penerbit PT Raja Grafindo 
B. Arifin

Persada.

Daryanto, \& Raharjo, M. (2016). Teori Komunikasi, Yogyakarta: Gava Media, cetakan I.n

Rahmat, J. (2002). Metode Penelitian Komunikasi, Bandung : Remaja Rosda Karya.

Muhtadi, Asep S. (2012). Komunikasi Dakwah. Bandung: Simbiosa Rekatama Media.

Moleong, Lexy J. (2006). Metodologi Penelitian Kualitatif; Edisi Revisi, Bandung : Remaja Rosda Karya.

Muhtadi, A.S \& Safei, A. (2003) Metode Penelitian Dakwah, Bandung: Pustaka Setia. Sugiyono, (2017). Metode Penelitian Kualitatif, Bandung: Alfabeta.

Tasmara, T. (1997). Komunikasi Dakwah, Jakarta: Gaya Media Peratama.

Solehudin, D. (2016). Strategi Komunikasi Dakwah Syaikh Muhammad Abdul Gaos Saefullah Maslul dalam Pembinaan Akblak Ikbwan Tarekat. Tesis, Program Studi Komunikasi Penyiaran Islam, Program Pascasarjana Universitas Islam Negeri Sunan Gunung Djati Bandung.

Musbahudin, D. (2015). Strategi Dakwah Nahdatul Ulama Terhadap Masyarakat Pedesaan. Tesis, Program Studi Komunikasi Penyiaran Islam Program Pascasarjana Universitas Islam Negeri Sunan Gunung Djati Bandung.

Suwarso, W.A. (2016). Strategi Komunikasi Penyuluh Agama Islam di Daerah Perbatasan Indonesia-Malaysia. Tesis, Program Studi Komunikasi Penyiaran Islam pascasarjana Universitas Islam Negeri Sunan Gunung Djati Bandung. 